\title{
A Case Study on the Association of Variation of Bitter-Taste Receptor Gene TAS2R38 with the Height, Weight and Energy Intake in Japanese Female College Students
}

\author{
Hiroko INOUE $^{1, *}$, Kimiko YAMAKAWA-KoBAYASHI ${ }^{2, *}$, Yuichi SuZUKI ${ }^{3, * *}$, Teruyo NAKANO ${ }^{3}$, \\ Hisayoshi HAYASHI $^{3}$ and Toshiko KUWANO ${ }^{1}$ \\ ${ }^{1}$ Laboratory of Nutrition Education, ${ }^{2}$ Laboratory of Human Genetics and ${ }^{3}$ Laboratory of Physiology, \\ School of Food and Nutritional Sciences, University of Shizuoka, Yada 52-1, \\ Suruga-ku, Shizuoka 422-8526, Japan \\ (Received April 9, 2012)
}

\begin{abstract}
Summary One of the critical factors that determines individual differences in dietary behavior and nutritional status is the sensory-affecting quality of food, in particular its taste. Variation of one bitter taste receptor gene, TAS2R 38, which is associated with the differential sensitivity to phenylthiocarbamide (PTC) and 6-n-propylthiouracil (PROP), has been demonstrated to affect the dietary intake pattern. A case study was performed to examine the association of the TAS2R 38 genotypes/haplotypes with the body size (height, weight and BMI) and with the food and nutrient intake. Eighty-four college students, all females, with an age range of 18-21 y were recruited from the University of Shizuoka. The genotypes of two common single nucleotide polymorphisms in TAS2R38 (A49P and I296V) were determined by PCR-restriction fragment length polymorphism (RFLP) method. The height, weight and body mass index (BMI), and (in a subgroup of 47 subjects) food and nutrition intake estimated from $3 \mathrm{~d}$ of food recording, were compared between homozygotes for the PTC/PROP-nontaster haplotype (AI haplotype) and carriers with the PTC/ PROP-taster haplotype (PV haplotype). The results show that the homozygotes with AI haplotype were taller and heavier than the carriers of PV haplotype, while BMI values were similar between them. The former group also had higher energy and carbohydrate intakes than the latter group. Neither vegetable nor dairy product intake was different between the homozygotes with AI haplotype and the carriers of PV haplotype. In conclusion, the PTC/ PROP-nontaster TAS2R 38 genotype/haplotype was associated with height and weight but not with BMI, which may in turn have influenced the energy and carbohydrate intakes.
\end{abstract}

Key Words food intake, BMI, PROP, dietary behavior

Food choice and dietary practice affect the growth and composition of the body, and have important implications for nutrition-related chronic diseases (1-3). One of the critical factors that determine dietary behavior is the sensory-affecting quality of food, in particular taste. Data have been presented that variation of the genes involved in taste perception may account for some of the individual differences in food selection, nutritional status, and nutrition-related disease susceptibility (4-6).

The human bitter taste receptor gene family (hTAS2R) comprises about 25 members belonging to $\mathrm{G}$ proteincoupled receptors (7-11). These are expressed in the taste receptor cells of taste buds in the oral cavity, and also in the mucosa of the gastrointestinal tract (12-14). TAS2R 38 is probably best-studied member of the TAS $2 R$ family, since its variation has predicted to a considerable but not perfectly, traits related to differing sensitivity to the synthetic compounds phenylthiocarbamide (PTC) and 6-n-propylthiouracil (PROP), i.e., the PTC/PROP tasters and nontasters (15-20). There are three com-

\footnotetext{
**To whom correspondence should be addressed.

E-mail: yuichi@smail.u-shizuoka-ken.ac.jp
}

mon single nucleotide polymorphisms in the TAS2R 38 gene that result in amino acid substitutions in the protein (A49P, V262A and I296V). These show strong linkage disequilibrium, giving rise to the two common haplotypes, $\mathrm{A}(\mathrm{V}) \mathrm{I}$ and $\mathrm{P}(\mathrm{A}) \mathrm{V}$. The PTC/PROP-taster individuals generally possess one or two $\mathrm{P}(\mathrm{A}) \mathrm{V}$ haplotypes, whereas nontaster individuals are homozygous for the A(V)I haplotype (15-20). Such individual difference in the PTC/PROP taste status or TAS2R38 variation has been demonstrated to result in differences in liking for such foods as some vegetables, fatty foods, spicy foods and alcoholic beverages (5). Such differences have also been suggested to affect the body mass index (BMI) or obesity, but with some controversial results $(5,21)$; for example, the PROP-taster phenotype has been reported to be associated with larger BMI under certain circumstances (22-26) but not in other cases (27-29). On the other hand, no association between the TAS $2 R 38$ genotype/haplotype and BMI has been reported (30-33). In contrast to BMI and obesity, relatively little information is available for the effect on height of variation in the PTC/PROP sensitivity or TAS2R38 genotype/haplotype.

The purpose of this study was, therefore, to further 
investigate the influence of variation in the TAS $2 R 38$ genotype/haplotype on individual differences in nutritional status and dietary behavior. As a case study, we examined the relationship of the TAS2R38 genotype/ haplotype with the body size (height, weight and BMI) and food and nutrient intakes of a group of female students at our university.

\section{METHODS}

Subjects. Eighty-seven female college students in the age range of 18-22 y were recruited from the university community. Their birth dates were in the years 19871991. The ethics committee of the University of Shizuoka approved the study protocol (no. 21-9), according to principles of the Declaration of Helsinki and all participants provided written informed consent.

Anthropometric measurements. The body height and weight of each subject were measured at 9:00-11:00 a.m. Each subject was allowed to eat breakfast and drink water freely before the measurements. The height was measured in the upright position with a stadiometer. The body weight was measured while wearing light clothes, and $1.0 \mathrm{~kg}$ was subtracted from the measured value to give the body weight value to be used. The body mass index (BMI) is defined as the weight in kilograms divided by the square of the height in meters.

Genetic analysis of the TAS2R 38 gene. Genomic DNA was isolated from buccal mucosa cells by using a Highpure PCR template preparation kit (Roche Diagnostics, Tokyo, Japan). We determined the genotypes of A48P and I296V polymorphisms for each subject by the PCR restriction fragment length polymorphism (PCR-RELP) method. We unfortunately were unable to determine the genotype of V262A. The haplotypes and their frequencies were estimated by the maximum-likelihood method with an EM-based algorithm, using the SNPAlyze program (Dynacom, Yokohama, Japan). We regarded the PV haplotype as a PTC/PROP-taster type, and the AI haplotype as a PTC/PROP-nontaster type.

Dietary assessment. A subset of subjects, who had registered for the nutrition education classes (by $\mathrm{T}$. Kuwano), was recruited for the dietary assessment. They completed food records of each meal, including weights, for three consecutive weekdays in June (within 1 mo after the anthropometric measurements). The food record for each subject was processed by Excel Eiyokun software (version 4.5; Kenpakusha, Tokyo) without knowing her TAS2R 38 genotype.

Statistical analysis. A comparison among three groups was analyzed by using ANOVA and the TukeyKramer test, and a two-group comparison was made by using an unpaired $t$-test. The statistical analyses were performed with the 18.0J software version (SPSS, Tokyo, Japan), the significance criterion for all tests being set at $p<0.05$.

\section{RESULTS}

\section{TAS2R 38 variation}

The distribution of TAS2R28 genotypes and haplotypes in the subjects is summarized in Table 1. The frequency of the AI haplotype was 0.43, suggesting that this haplotype was slightly less frequent than the PV haplotype, agreeing with the previously reported figures for those of Asian descent $(15,17)$.

Effect of TAS2R38 variation on the height, weight and BMI

We first compared the body size, i.e., height, weight and BMI, among the three groups with different TAS2R38 diplotypes (Fig. 1). The homozygotes for the AI haplotype were significantly taller and heavier than the heterozygotes for the PV and AI haplotypes, although not different from the homozygotes for the PV haplotype. On the other hand, there was no difference in BMI among the three groups. We then pooled the data for homozygotes of the PV haplotype and that for heterozygotes of the PV and AI haplotypes into a single group (PTC/PROP-taster group), and compared these with the data for the homozygotes of the AI haplotype

Table 1. Distribution of TAS2R38 genotypes and haplotypes in Japanese female college students.

\begin{tabular}{|c|c|c|c|c|}
\hline \multicolumn{2}{|c|}{ Genotype } & \multirow{2}{*}{ Haplotype } & \multirow{2}{*}{$\begin{array}{c}\text { Number of } \\
\text { subjects } \\
(n=87)\end{array}$} & \multirow{2}{*}{$\begin{array}{c}\text { Subject subset } \\
\text { involved in food } \\
\text { intake measurement } \\
\qquad(n=47)\end{array}$} \\
\hline A49P & $\mathrm{I} 296 \mathrm{~V}$ & & & \\
\hline PP & VV & $\mathrm{PV} / \mathrm{PV}$ & 26 & 14 \\
\hline PA & VI & $\mathrm{PV} / \mathrm{AI}$ & 43 & 25 \\
\hline $\mathrm{AA}$ & II & $\mathrm{AI} / \mathrm{AI}$ & 16 & 8 \\
\hline $\mathrm{PA}$ & VV & $\mathrm{PV} / \mathrm{AV}$ & 1 & 0 \\
\hline PP & VI & $\mathrm{PV} / \mathrm{PI}$ & 1 & 0 \\
\hline
\end{tabular}
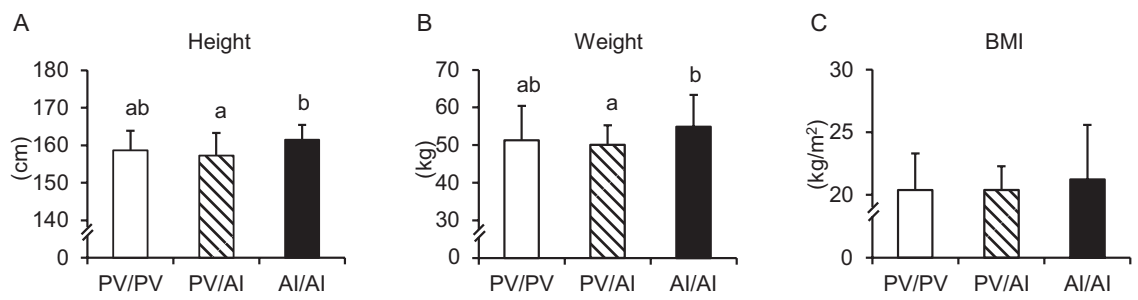

Fig. 1. Comparison of body size among the three major TAS2R38 diplotypes. A, Height; B, Weight; C, Body mass index (BMI), defined as the weight in kilograms divided by the square of the height in meters. Unfilled bars $(n=26)$, hatched bars $(n=42)$ and filled bars $(n=16)$ show subjects with respective diplotypes PV/PV, PV/AI, and AI/AI. One PV/AI diplotype, who had an eating disorder, and two minor diplotypes (Table 1) were excluded. Each value is the mean \pm SD. Means with different letters are different at $p<0.05$ by the Tukey-Kramer test. 
(PTC/PROP-nontaster group). As shown in Table 2, the homozygotes of the AI haplotype were significantly taller (by about $4 \mathrm{~cm}$ ) and heavier (by $4 \mathrm{~kg}$ ) than carriers of the PV haplotype, while BMI was not different between these two groups.

Effect of TAS2R 38 variations on the dietary intake

We next examined the relationships between the TAS2R 38 variations and the daily energy and nutrient intake. The subset of subjects recruited for dietary assessment showed that the homozygotes for the AI haplotype were significantly taller and probably heavier

Table 2. Body size and TAS2R 38 haplotype.

\begin{tabular}{cccc}
\hline Variable & $\begin{array}{c}\text { PV/PV and PV/AI } \\
(n=68)\end{array}$ & $\begin{array}{c}\text { AI/AI } \\
(n=16)\end{array}$ & $p$ \\
\hline Height $(\mathrm{cm})$ & $157.8 \pm 5.8$ & $161.5 \pm 3.9^{*}$ & 0.02 \\
Weight $(\mathrm{kg})$ & $50.5 \pm 6.9$ & $54.9 \pm 8.5^{*}$ & 0.03 \\
BMI $\left(\mathrm{kg} / \mathrm{m}^{2}\right)$ & $20.4 \pm 2.3$ & $21.2 \pm 4.3$ & 0.60
\end{tabular}

Each value is the mean \pm SD.

Differences were compared by Student's unpaired $t$-test. $* p<0.05$.

Table 3. Body size and TAS2R 38 haplotype in the subject subset involved in food intake measurement.

\begin{tabular}{lccc}
\hline \multicolumn{1}{c}{ Variable } & $\begin{array}{c}\mathrm{PV} / \mathrm{PV} \text { and PV/AI } \\
(n=39)\end{array}$ & $\begin{array}{c}\mathrm{AI} / \mathrm{AI} \\
(n=8)\end{array}$ & $p$ \\
\hline Height $(\mathrm{cm})$ & $158.8 \pm 5.67$ & $163.8 \pm 3.35^{*}$ & 0.02 \\
Weight $(\mathrm{g})$ & $51.4 \pm 5.9$ & $55.7 \pm 11.3$ & 0.13 \\
BMI $\left(\mathrm{kg} / \mathrm{m}^{2}\right)$ & $20.4 \pm 2.3$ & $20.8 \pm 4.4$ & 0.74 \\
\hline
\end{tabular}

Each value is the mean \pm SD.

Differences were compared by Student's unpaired $t$-test. ${ }^{*} p<0.05$. than the carriers of the PV haplotype (Table 3). BMI did not differ between these two groups.

Figure 2 shows that the daily energy intake by the homozygotes of the AI haplotype was significantly greater than those by either the homozygotes of the PV haplotype or heterozygotes of the PV and AI haplotypes. In addition, the daily carbohydrate, protein and fat intakes tended to be higher by homozygotes of the AI haplotype, although only the difference between the carbohydrate intake by homozygotes of the AI haplotype and by heterozygotes of the PV and AI haplotypes was significant. We again pooled the data for the homozygotes of the PV haplotype with those for the heterozygotes of the PV and AI haplotypes into one group, and compared these with the data for homozygotes of the AI haplotype (Table 4). The result shows that the homozygotes of the AI haplotype had significantly higher energy and carbohydrate intakes. The mean daily intake values of protein, fat and carbohydrate by homozygotes of the AI haplotype were greater by $14.0 \%, 14.0 \%$ and $17.2 \%$, respectively, these values agreeing well with the $15.2 \%$ greater daily energy intake by this group. When the individual energy intake was divided by each basal metabolic rate (calculated from the height, weight, age and sex for each subject) (34), the value of homozygotes of the AI haplotype was no longer significantly higher than that of carriers of the PV haplotype (Table 4). The higher energy intake by homozygotes of the AI haplotype may therefore be explained, if not totally, by their greater body size. Neither the sodium intake nor sodium/energy intake ratio was associated with the TAS2R 38 haplotypes (Fig. 2 and Table 4), in agreement with previous reports $(31,35)$.

We then examined the relationships between the TAS2R 38 haplotype and intake of vegetable and dairy products (Table 5), as it has been shown that TAS $2 R 38$ variations or sensitivity to PROP might influence the consumption of vegetables $(30,36-39)$. However,
A

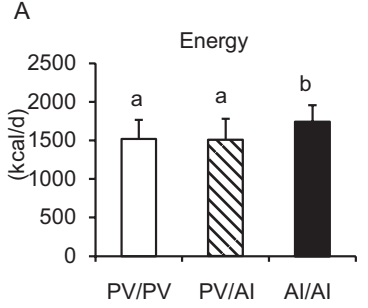

D

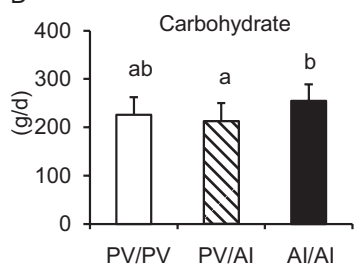

B

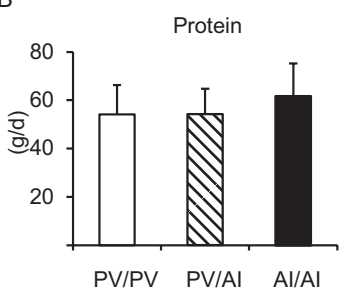

E

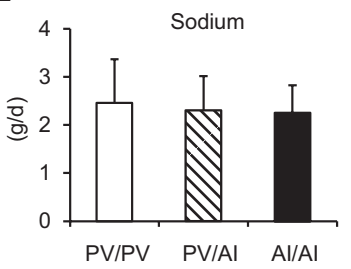

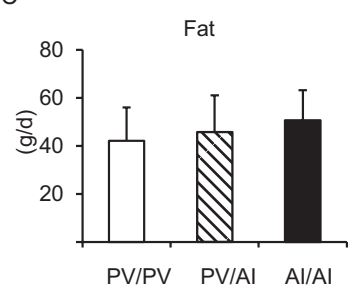


Table 4. Nutrient intake and TAS2R38 haplotype.

\begin{tabular}{lccc}
\hline \multicolumn{1}{c}{ Nutrient intake } & $\begin{array}{c}\text { PV/PV and PV/AI } \\
(n=39)\end{array}$ & $\begin{array}{c}\text { AI/AI } \\
(n=8)\end{array}$ & $p$ \\
\hline Energy $(\mathrm{kcal} / \mathrm{d})$ & $1,512 \pm 259$ & $1,742 \pm 216^{*}$ & 0.02 \\
Energy/BMR $^{1}$ & $1.284 \pm 0.222$ & $1.396 \pm 0.213$ & 0.20 \\
Protein $(\mathrm{g} / \mathrm{d})$ & $54.2 \pm 11.0$ & $61.8 \pm 13.5$ & 0.10 \\
Fat $(\mathrm{g} / \mathrm{d})$ & $44.4 \pm 14.7$ & $50.6 \pm 12.5$ & 0.30 \\
Carbohydrate $(\mathrm{g} / \mathrm{d})$ & $217.3 \pm 37.4$ & $254.7 \pm 34.4^{*}$ & 0.01 \\
Sodium $(\mathrm{mg} / \mathrm{d})$ & $2,356 \pm 781$ & $2,256 \pm 566$ & 0.73 \\
Sodium/energy $^{2}$ & $1.56 \pm 0.51$ & $1.31 \pm 0.35$ & 0.18 \\
\hline
\end{tabular}

Each value is the mean \pm S.D.

Differences were compared by Student's unpaired $t$-test. ${ }^{*} p<0.05$.

${ }^{1}$ BMR: basal metabolic rate calculated by the equation proposed by Ganpule et al. (34), BMR $(\mathrm{kcal} / \mathrm{d})=(0.1238+$ $0.0481 \times$ weight $+0.0234 \times$ height $-0.0138 \times$ age $0.5473 \times 2) \times 1,000 / 4.186$.

${ }^{2}$ Sodium intake divided by each energy intake.

Table 5. Vegetable and dairy product intake for TAS2R 38 haplotypes.

\begin{tabular}{|c|c|c|c|}
\hline Food group & $\begin{array}{c}\mathrm{PV} / \mathrm{PV} \text { and } \mathrm{PV} / \mathrm{AI} \\
(n=39)\end{array}$ & $\begin{array}{l}\mathrm{AI} / \mathrm{AI} \\
(n=8)\end{array}$ & $p$ \\
\hline Total vegetables $(\mathrm{g} / \mathrm{d})$ & $207.8 \pm 114.6$ & $220.5 \pm 113.9$ & 0.78 \\
\hline $\begin{array}{l}\text { Brassicaceae } \\
\text { vegetables }(\mathrm{g} / \mathrm{d})\end{array}$ & $49.0 \pm 55.2$ & $49.7 \pm 55.8$ & 0.97 \\
\hline $\begin{array}{l}\text { Total dairy } \\
\text { products }(\mathrm{g} / \mathrm{d})\end{array}$ & $153.1 \pm 111.3$ & $182.4 \pm 121.3$ & 0.51 \\
\hline Milk $(\mathrm{g} / \mathrm{d})^{1}$ & $81.3 \pm 95.7$ & $78.5 \pm 94.2$ & 0.94 \\
\hline
\end{tabular}

Each value is the mean \pm SD.

Differences were compared by Student's unpaired $t$-test.

${ }^{1}$ Includes milk consumed only as a drink but not as a food ingredient.

the vegetable intake was no different as a function of TAS2R 38 haplotype. We then specifically examined the intake of vegetables belonging to Brassicaceae family which contain bitter compounds, glucosinolates, as previous studies have reported that PTC/PROP-tasters had a lower consumption of glucosinolate-containing vegetables than non-tasters (40-42). However, no association between the TAS2R 38 haplotype and Brassicaceae vegetable intake was evident, in agreement with a recent report (43). We finally analyzed the dairy product intake, because previous studies have reported that the PTC/PROP-taste status was implicated in the liking for dairy products $(35,44,45)$. However, we found no association between the TAS2R 38 haplotype and the intake of total dairy products by the present subjects (Table 5). In addition, the cow's milk intake was not associated with the TAS2R 38 haplotype; cow's milk intake during childhood is believed to be associated with growth and height in adulthood (46-50).

\section{DISCUSSION}

A significant finding of the present study based on a group of female college students is that the homozygotes for the AI haplotype (PTC/PROP-nontaster haplotype) were greater in height and weight than the carriers with the PV haplotype (PTC/PROP-taster haplotype). Our result demonstrates, probably for the first time, that the TAS2R 38 variation is associated with height: previous studies on females have demonstrated no difference in the height or weight as a function of the PROP-taste status (31) or of the TAS2R38 variation (30). Yackinous and Guinard (51) have also reported that the PROP-taster status determined by PROP sensitivity did not significantly affect either the height or weight in either young adult men or women. However, the results of their report show the mean value for height being greater by $4-8 \mathrm{~cm}$ and that for weight by $0.1-3.6 \mathrm{~kg}$ for the PROP-nontasters than for the PROP-tasters (cf. Table 1 in their report), these differences being similar to those observed with our TAS2R 38 haplotype study on young adult women (Tables 2 and 3 ).

One possible mediator that may link the TAS $2 R 38$ haplotype to higher stature is cow's milk consumption during childhood. There is evidence that cow's milk consumption was associated with a high growth rate and height in adulthood, although the exact mechanism and health implications for this remain to be understood (46-50). Previous studies on children have shown the acceptance rating for cow's milk to be higher for PROPnontasters than -tasters, whether it was examined as a function of PROP sensitivity (45) or of variations in the TAS2R 38 gene $(35,44)$. Contrary to our expectations, however, we could not detect in the present study any difference in the cow's milk intake or dairy food intake between homozygotes of the AI haplotype and carriers of the PV haplotype (Table 5).

Our results show that BMI was no different among the TAS2R38 haplotypes (Table 2). The relationship examined as a function of the TAS2R 38 variations has shown BMI to be no different between the PTC/PROP-taster and -nontaster haplotype groups (30-33), in agreement with the present result. The relationship examined as a function of the PTC/PROP-sensitivity phenotypes has also shown BMI not to be associated with the sensitivity in most studies (27-29). However, the results of several studies have shown the PROP-sensitivity status to be negatively associated with BMI (22-26). Disparity between the influence of the TAS2R 38 variations and PTC/PROP-taster phenotype on BMI may be explained by hypothesis that phenotypic PTC/PROP-tasters and -nontasters capture additional taste information that is not provided by the TAS $2 R 38$ variations.

Our results demonstrate that the homozygotes of the AI haplotype had a higher dietary energy intake than the carriers of the PV haplotype (Fig. 2, Table 4). This appears to have resulted from the greater intake of all three macronutrients, although significance was only evident for the carbohydrate intake. The higher energy intake by homozygotes of the AI haplotype in our study was probably the result, rather than the cause, of the increased height (and weight) in this group, since the difference in energy intake between the two TAS2R 38 
haplotype groups was weakened when the individual energy intake was divided by individual predictive basal metabolic rate i.e. normalized by body size (Table 4) (34). Previous studies have shown that pre-adolescent children and adult women with the PROP-nontaster phenotype consumed more energy than the PROP tasters $(29,31)$ without any noticeable change in the intake ratio among the three macronutrients (i.e. a greater intake of all three macronutrients), in agreement with our results (Table 4), although the influence of body size on energy consumption has not been examined.

In summary, the present results obtained from a group of female college students show that the homozygotes of the AI haplotype (PTC/PROP-nontaster haplotype) were taller and heavier (although having similar BMI), and had a greater energy intake, than the carriers of the PV haplotype (PTC/PROP-taster haplotype). It remains to be determined whether there is a similar association of the TAS2R 38 variations with height and weight, first in other Japanese young female groups and then in other populations of different races, generations and sexes. Our findings reinforce the notion that variation in taste receptor genes influences individual differences in food intake and nutritional status (4-6). Elucidation of the precise mechanisms underlying an association between the TAS $2 R 38$ variations and body size may be important not only for understanding the nutritional role of taste receptors, but may also be relevant to nutrition education, particularly for children, because the impact of taste gene variations on dietary preference would be stronger in children than in adults $(35,52,53)$.

\section{Statement of potential conflict of interest}

No potential conflict of interest was reported by the authors.

\section{Funding/Support}

This study was partly supported by a Grant-in-Aid from the Ministry of Education, Science, Sports and Culture of Japan (no. 21700762) to H.I., by Grant-in-Aid for the Global COE Program from the Ministry of Education, Culture, Sports, Science and Technology of Japan (MEXT) to K. Y.-K., and by the Salt Science Research Foundation (no. 0909) to Y.S.

\section{Acknowledgments}

We thank Tony Innes and Philip Hawke for helping us to edit the English text.

\section{REFERENCES}

1) World Health Organization. 2003. Diet, nutrition and the prevention of chronic diseases. World Health Organ Tech Rep Ser 916: 1-12.

2) Uauy R, Kain J, Mericq V, Rojas J, Corvalán C. 2008. Nutrition, child growth, and chronic disease prevention. Ann Med 40: 11-20.

3) Batty GD, Shipley MJ, Gunnell D, Huxley R, Kivimaki M, Woodward M, Lee CM, Smith GD. 2009. Height, wealth, and health: an overview with new data from three longitudinal studies. Econ Hum Biol 7: 137-152.

4) Bachmanov AA, Beauchamp GK. 2007. Taste receptor genes. Апnи Rev Nutr 27: 389-414.

5) Tepper BJ. 2008. Nutritional implications of genetic taste variation: the role of PROP sensitivity and other taste phenotypes. Annu Rev Nutr 28: 367-388.

6) Garcia-Bailo B, Toguri C, Eny KM, El-Sohemy A. 2009. Genetic variation in taste and its influence on food selection. OMICS 13: 69-80.

7) Adler E, Hoon MA, Mueller KL, Chandrashekar J, Ryba NJ, Zuker CS. 2000. A novel family of mammalian taste receptors. Cell 100: 693-702.

8) Chandrashekar J, Mueller KL, Hoon MA, Adler E, Feng L, Guo W, Zuker CS, Ryba NJ. 2000. T2Rs function as bitter taste receptors. Cell 100: 703-711.

9) Matsunami H, Montmayeur JP, Buck LB. 2000. A family of candidate taste receptors in human and mouse. Nature 404: 601-604.

10) Mueller KL, Hoon MA, Erlenbach I, Chandrashekar J, Zuker CS, Ryba NJ. 2005. The receptors and coding logic for bitter taste. Nature 434: 225-229.

11) Meyerhof W, Batram C, Kuhn C, Brockhoff A, Chudoba E, Bufe B, Appendino G, Behrens M. 2010. The molecular receptive ranges of human TAS2R bitter taste receptors. Chem Senses 35: 157-170.

12) Wu SV, Chen MC, Rozengurt E. 2005. Genomic organization, expression, and function of bitter taste receptors (T2R) in mouse and rat. Physiol Genomics 22: 139-149.

13) Rozengurt E. 2006. Taste receptors in the gastrointestinal tract. I. Bitter taste receptors and alpha-gustducin in the mammalian gut. Am J Physiol Gastrointest Liver Physiol 291: G171-G177.

14) Kaji I, Karaki S, Fukami Y, Terasaki M, Kuwahara A. 2009. Secretory effects of a luminal bitter tastant and expressions of bitter taste receptors, T2Rs, in the human and rat large intestine. Am J Physiol Gastrointest Liver Physiol 296: G971-G981.

15) Kim UK, Jorgenson E, Coon H, Leppert M, Risch N, Drayna D. 2003. Positional cloning of the human quantitative trait locus underlying taste sensitivity to phenylthiocarbamide. Science 299: 1221-1225.

16) Prodi DA, Drayna D, Forabosco P, Palmas MA, Maestrale GB, Piras D, Pirastu M, Angius A. 2004. Bitter taste study in a sardinian genetic isolate supports the association of phenylthiocarbamide sensitivity to the TAS2R 38 bitter receptor gene. Chem Senses 29: 697-702.

17) Wooding S, Kim UK, Bamshad MJ, Larsen J, Jorde LB, Drayna D. 2004. Natural selection and molecular evolution in PTC, a bitter-taste receptor gene. Am J Hum Genet 74: 637-646.

18) Bufe B, Breslin PA, Kuhn C, Reed DR, Tharp CD, Slack JP, Kim UK, Drayna D, Meyerhof W. 2005. The molecular basis of individual differences in phenylthiocarbamide and propylthiouracil bitterness perception. Curr Biol 15: 322-327.

19) Kim U, Wooding S, Ricci D, Jorde LB, Drayna D. 2005. Worldwide haplotype diversity and coding sequence variation at human bitter taste receptor loci. Hum Mutat 26: 199-204.

20) Wooding S. 2006. Phenylthiocarbamide: a 75-year adventure in genetics and natural selection. Genetics 172: 2015-2023.

21) Hayes JE. 2010. Response to "Lack of relation between bitter taste receptor TAS2R38 and BMI in adults." Obesity (Silver Spring) 18: 433.

22) Tepper BJ, Ullrich NV. 2002. Influence of genetic taste sensitivity to 6-n-propylthiouracil (PROP), dietary 
restraint and disinhibition on body mass index in middle-aged women. Physiol Behav 75: 305-312.

23) Goldstein GL, Daun H, Tepper BJ. 2005. Adiposity in middle-aged women is associated with genetic taste blindness to 6-n-propylthiouracil. Obes Res 13: 1017-1023.

24) Tepper BJ, Koelliker Y, Zhao L, Ullrich NV, Lanzara C, d'Adamo P, Ferrara A, Ulivi S, Esposito L, Gasparini P. 2008. Variation in the bitter-taste receptor gene TAS2R38, and adiposity in a genetically isolated population in Southern Italy. Obesity (Silver Spring) 16: 2289-2295.

25) Keller KL, Reid A, MacDougall MC, Cassano H, Song JL, Deng L, Lanzano P, Chung WK, Kissileff HR. 2009. Sex differences in the effects of inherited bitter thiourea sensitivity on body weight in 4-6-year-old children. Obesity (Silver Spring) 18: 1194-1200.

26) Feeney E, O'Brien S, Scannell A, Markey A, Gibney ER. 2011. Genetic variation in taste perception: does it have a role in healthy eating? Proc Nutr Soc 70: 135-143.

27) Drewnowski A, Kristal A, Cohen J. 2001. Genetic taste responses to 6-n-propylthiouracil among adults: a screening tool for epidemiological studies. Chem Senses 26: $483-489$.

28) Keller KL, Tepper BJ. 2004. Inherited taste sensitivity to 6-n-propylthiouracil in diet and body weight in children. Obes Res 12: 904-912.

29) Goldstein GL, Daun H, Tepper BJ. 2007. Influence of PROP taster status and maternal variables on energy intake and body weight of pre-adolescents. Physiol Behav 90: 809-817.

30) Timpson NJ, Christensen M, Lawlor DA, Gaunt TR, Day IN, Ebrahim S, Davey Smith G. 2005. TAS2R38 (phenylthiocarbamide) haplotypes, coronary heart disease traits, and eating behavior in the British Women's Heart and Health Study. Am J Clin Nutr 81: 1005-1011.

31) Drewnowski A, Henderson SA, Cockroft JE. 2007. Genetic sensitivity to 6-n-propylthiouracil has no influence on dietary patterns, body mass indexes, or plasma lipid profiles of women. J Am Diet Assoc 107: 1340-1348.

32) Sausenthaler S, Rzehak P, Wichmann HE, Heinrich J. 2009. Lack of relation between bitter taste receptor TAS2R 38 and BMI in adults. Obesity (Silver Spring) 17: 937-938, author reply 939.

33) Dotson CD, Shaw HL, Mitchell BD, Munger SD, Steinle NI. 2010. Variation in the gene TAS2R38 is associated with the eating behavior disinhibition in Old Order Amish women. Appetite 54: 93-99.

34) Ganpule AA, Tanaka S, Ishikawa-Takata K, Tabata I. 2007. Interindividual variability in sleeping metabolic rate in Japanese subjects. Eur J Clin Nutr 61: 1256-1261.

35) Mennella JA, Pepino MY, Reed DR. 2005. Genetic and environmental determinants of bitter perception and sweet preferences. Pediatrics 115: 216-222.

36) Turnbull B, Matisoo-Smith E. 2002. Taste sensitivity to 6-n-propylthiouracil predicts acceptance of bitter-tasting spinach in 3-6-y-old children. Am J Clin Nutr 76: 1101-1105.

37) Basson MD, Bartoshuk LM, Dichello SZ, Panzini L, Weiffenbach JM, Duffy VB. 2005. Association between 6-n-propylthiouracil (PROP) bitterness and colonic neoplasms. Dig Dis Sci 50: 483-489.

38) Dinehart ME, Hayes JE, Bartoshuk LM, Lanier SL, Duffy VB. 2006. Bitter taste markers explain variability in vegetable sweetness, bitterness, and intake. Physiol Behav 87: 304-313.

39) Duffy VB, Hayes JE, Davidson AC, Kidd JR, Kidd KK, Bartoshuk LM. 2010. Vegetable intake in college-aged adults is explained by oral sensory phenotypes and TAS2R 38 genotype. Chemosens Percept 3: 137-148.

40) Bell KI, Tepper BJ. 2006. Short-term vegetable intake by young children classified by 6-n-propylthoiuracil bittertaste phenotype. Am J Clin Nutr 84: 245-251.

41) Sandell MA, Breslin PA. 2006. Variability in a tastereceptor gene determines whether we taste toxins in food. Curr Biol 16: R792-R794.

42) Sacerdote C, Guarrera S, Smith GD, Grioni S, Krogh V, Masala G, Mattiello A, Palli D, Panico S, Tumino R, Veglia F, Matullo G, Vineis P. 2007. Lactase persistence and bitter taste response: instrumental variables and mendelian randomization in epidemiologic studies of dietary factors and cancer risk. Am J Epidemiol 166: 576-581.

43) Baranowski T, Baranowski JC, Watson KB, Jago R, Islam N, Beltran A, Martin SJ, Nguyen N, Tepper BJ. 2011. 6-n-propylthiouracil taster status not related to reported cruciferous vegetable intake among ethnically diverse children. Nutr Res 31: 594-600.

44) Anliker JA, Bartoshuk L, Ferris AM, Hooks LD. 1991. Children's food preferences and genetic sensitivity to the bitter taste of 6-n-propylthiouracil (PROP). Am J Clin Nutr 54: 316-320.

45) Keller KL, Steinmann L, Nurse RJ, Tepper BJ. 2002. Genetic taste sensitivity to 6-n-propylthiouracil influences food preference and reported intake in preschool children. Appetite 38: 3-12.

46) Takahashi E. 1984. Secular trend in milk consumption and growth in Japan. Hum Biol 56: 427-437.

47) Okada T. 2004. Effect of cow milk consumption on longitudinal height gain in children. Am J Clin Nutr 80: 1088-1089, author reply 1089-1090.

48) Hoppe C, Mølgaard C, Michaelsen KF. 2006. Cow's milk and linear growth in industrialized and developing countries. Annu Rev Nutr 26: 131-173.

49) Berkey CS, Colditz GA, Rockett HR, Frazier AL, Willett WC. 2009. Dairy consumption and female height growth: prospective cohort study. Cancer Epidemiol Biomarkers Prev 18: 1881-1887.

50) de Beer H. 2012. Dairy products and physical stature: A systematic review and meta-analysis of controlled trials. Econ Hum Biol 10: 299-309.

51) Yackinous CA, Guinard JX. 2002. Relation between PROP (6-n-propylthiouracil) taster status, taste anatomy and dietary intake measures for young men and women. Appetite 38: 201-209.

52) Navarro-Allende A, Khataan N, El-Sohemy A. 2008. Impact of genetic and environmental determinants of taste with food preferences in older adults. J Nutr Elder 27: 267-276.

53) Mennella JA, Pepino MY, Duke FF, Reed DR. 2010. Age modifies the genotype-phenotype relationship for the bitter receptor TAS2R 38. BMC Genet 11: 60. 